\title{
Evolutionary Love and Companionate Marriage in Jane Austen's Novel Pride and Prejudice
}

\author{
Dr. Khalil Abdul-Hameed Mohammed Saif Alquraidhy \\ Department of English, College of Sciences and Arts, \\ University of Bisha, Saudi Arabia \\ kalquraidhy@ub.edu.sa, kalquraidhy@gmai.com
}

DOI: http://doi.org/ 10.36892/ijlls.v3i1.478

\begin{tabular}{l} 
Received: \\
04/01/2021 \\
\hline Accepted: \\
09/02/2021 \\
\\
\hline Keywords: \\
Jane Austen, Pride \\
and Prejudice, \\
Evolutionary Love, \\
Companionate \\
Marriage.
\end{tabular}

In the novel Pride and Prejudice, Jane Austen has selected the basic unit of human relationship, the family. In the family we have several forms of relationships. The most fundamental relationship is there in terms of love and marriage which form the basic theme of the novel Pride and Prejudice. In the research paper, love has been analyzed as an evolutionary process. It is the logic of love that unfolds the characteristics of its main characters. Their love has been brought out from the usual shadow of emotionalism and sentimentality. It has been put under the direct control of their ratiocination. And that is the peculiarity of Austen's treatment of love. The characters have passed through various stages of love so that, ultimately, they reach the final stage of passionate love, shorn of their pride and prejudice. From there they move to marriage which I have called the companionate marriage. When they enter matrimony, they enter it as pure companions moving together, hand in hand, in their life. It is not the marriage as established and defined by the early nineteenth century society. Austen's lovers do not abjure the society, yet they do not accept this society's concept of marriage completely. As they have shaped their love, so they will shape their marriage.

\section{INTRODUCTION}

This paper is a try to discuss and analyze the theme of love and marriage in a new way to show the peculiarity of Jane Austen's treatment of love as an evolutionary love and marriage as a companionate marriage between Darcy and Elizabeth. Thus, the researcher made this research paper in two sections. The first section will discuss and analyze the concept of love as an evolutionary love and the second section will discuss the concept of marriage as a companionate marriage which shows the creativity of Jane Austen in presenting this fundamental human relationship which is the basic unit of human relationship, the family.

\section{EVOLUTIONARY LOVE IN JANE AUSTEN'S PRIDE AND PREJUDICE}

Among all human relations, love holds the prime position in the novels of Jane Austen. This love can best be described as an evolutionary love-a love between a man and a woman that slowly and gradually evolves itself out. ${ }^{1}$ That term can also be applied to the love

\footnotetext{
1 -A few critics have talked of the evolution of love in terms of the actual events or incidents taking place in the novel. They have been explained as turning-points in the relationship between Elizabeth and Darcy.
} 
as depicted in the novels of her contemporaries. But then there is a difference in the very process of evolution adopted by Jane Austen and by other romantic novelists. Jane Austen takes recourse to the ratiocinative process of evolution where the man and the woman work out their love with the help of their reason. Their love, as usual, also starts with their first meeting; the eyes meet and the hearts respond. There is some give and take at the level of the hearts. But it is all tacit and passive. The hearts here are not aggressive; there is no eagerness to jump over the fence. It is a love forged by caution and tempered by time. Each one adopts the policy of wait and watch. For from now on the rein of love is taken over by their reasons; the hearts recede into the background. The reason now starts its operation by taking into consideration all the pros and cons of love into which the two hearts have taken a plunge. The reason starts with the inquiry whether the plunge taken is correct in terms of the well-being of both the man and the woman involved. The man has his own considerations, sometimes tacit and sometimes loud. He takes into consideration the family-his family and the other family, the society and the personality of the woman involved and so many other considerations even to the smallest details. The woman has other considerations. Typical to the society of Jane Austen, there is even the consideration of money and security of life in terms of a secure home and hearth. But the primary concern is about the man involved - his character - mental and spiritual, and his ability to adapt and accept the woman as she is and not as he desires her to be. These considerations on the part of both the man and the woman start creating hurdles in their way. In the novel, these hurdles, arising out of these considerations, take on the form of Pride and Prejudice so much so that the man and the woman start thinking that, instead of loving each other, they hate each other. The psychologists say that simply because desire is not expressed, it does not cease to exist; repressed, it does not disappear. Instead, it is sympathetically displaced, in the form of hatred. In that form, it returns with repetitive insistence in a concealed form. Love in Austen is a matter of nurture triumphing over nature. And that can explain Charlotte Bronte's misunderstanding of Austen; with Charlotte Bronte, the opposite is the case. So Austen and Charlotte Bronte, in matters of love, stand at two opposite poles.

At this stage, the difference between the evolutionary processes adopted by Austen and her other contemporaries becomes clear. In the case of her contemporaries, the hurdles are created at two levels, both extraneous-at the level of their actions and at the level of the society. The men and women are seriously engaged in pursuing their love. At some stage, they take a false step, commit some error of judgment and do something wrong. The monster hurdle then stands on the way and stares them in their faces. The society, on its own, also sometimes creates the hurdle. In the case of Austen, the hurdles are purely internal and mental. It all results from their ratiocinativeness. ${ }^{2}$ They are like the scientist keeping an eye on the object of love through the lens of their microscope-the reason. The microscope exposes layer after layer of the object of love. Like the scientist, they react to each and every

T.Vasudeva Reddy in " Jane Austen; The Matrix of Matrimony " (1987: 19-48) and David Monaghan in " Jane Austen Structure and social Vision " (1980: 64-92) have dwelt, in detail, upon these external events helping the growth of love.

My argument is that Austen's lovers are not so much affected directly by these external events. These influence them only through their minds. The actual evolution takes place at the level of their minds and not at the level of these events. There lies the significance of evolution, of ' Evolutionary Love'. The primary evolution takes place at the level of the mind and the spirit.

2 -Many critics have referred to the presence of the elements of reason in the lives of the lovers of Jane Austen. Shushila Singh in " Jane Austen " - "Her Concept of Social Life " ( 1981: 12) has just referred to " reasonableness in everything. " Reeta Sahney in "Jane Austen's Heroes" (1990: 32) just talks of the " amalgam of ... both the head and the heart ." Lord David Cecil in his book " Jane Austen: The Leslie Stephen Lecture"(1935: 21-2 )quoted by Judith O'Neil (edt.) in the book " Critics on Jane Austen" (1971: 34 ) talks of "Love itself ...justified by reason ". In her novel, the reason is not mere reasonableness, nor is it important only when joined to heart. It is not there simply for the justification of love. The reason is of primary importance. Without reason no love is possible. Her lovers are primarily ratiocinative. It is this argument that I have developed in this chapter. 
exposure and form their opinion. The opinions are divided; the conclusions drawn are different; they diverge; this mental divergence is the hurdle. But they do not stop; this divergence rather prompts them to find out the common points, if there are any. Until and unless they are found out, they cannot meet. The search is prolonged because of the twists and turns involved. Here, Austen reveals herself as a true psychologist in the form of a novelist who asks her characters to find their love first in their own mind, heart, and psyche, to find out the true spirit of love and to understand as to what it is and in what form they are ready to accept it. Until and unless they are very clear, in their minds, about its true nature, shape, form, and spirit, they are not mature enough to make true love. So they must first be clear in their own minds. Until that clarity of vision is achieved, they will have hurdles, first at the level of their own minds and spirits and then at the level of the minds and spirits of the others. So with Austen's man and woman, the hurdles are always at the mental level. It is thus all purely internal. There is no external hurdle; even if it is there it is so minor that it is crossed over once the mental clarity and strength are achieved. In this sense, love in Austen takes a psychological character and, thus, every effort is made to secure it purely at the mental level. It is here that it evolves and fructifies. And that is one of the distinct characteristics of love in Austen. It is not purely emotional as in other novelists.

The pure passion of love only comes after. It is evident to those readers only who read her novels minutely. It escapes them since they do not find any evidence of this sweeping passion at the beginning of the novel as in the novels of her contemporaries and in the novels of Charlotte Bronte. We may guess here as to why and how Charlotte missed it in the novels of Austen and charged Austen with the lack of passion. In Austen, passionate love is the destination to which the lovers have to move through the devious and labyrinthine ways of love. Laboriously, assiduously and persistently they have to evolve it in their life with the use of their mental faculty. They have to search it out; it is not something to be found easily by the roadside and it is also not something that can be found by everybody. Some stop by the way like Charlotte Lucas of Pride and Prejudice; she is the best friend of Elizabeth - the heroine of the novel. But her mental make-up is different. She is also in search of love, like Elizabeth. But she does not have the mental tenacity of Elizabeth and the patience to search out the pure love. By the way, she soon gets tired and, on the first opportunity, she stops and picks up the Collins-the priest, in the name of security of home and hearth. Thus, one woman drops the search for the pure passionate love of the psyche. The feeling of insecurity of life tilts the balance in favor of marriage that guarantees monetary comfort and social security. Money is preferred to love. She cannot wait for love to happen first. Once she has the security, love can take its own course. So, for her, love is not that important. It is subsidiary to other considerations.

Yet there is another searcher after pure love-Jane- the eldest daughter. Her love is mute; Bingley too is mute. Charlotte Bronte must have laughed at these dumb lovers. They love but they would not speak about this love. Others, especially Bingley's sister and Elizabeth -Jane's sister- recognize their love. Charlotte Lucas too understands this love and advises Jane to speak it out to Bingley. But Jane would not do that. Bingley expects her to express it. Darcy misunderstands her for she does not speak. To him, a mute love is no love. This misunderstanding he conveys to Bingley - his friend. Bingley might have taken Darcy's reading to be true. And so he leaves the place. Jane's silence has the support of her faith in her love and in Bingley. She can wait for him for she firmly believes that Bingley, one day, would come for he is a good man. For Austen, the goodness of the man is an essential trait of a lover desiring for pure love free from any extraneous consideration. It is this quality in the man that arouses her confidence. Their match is at the level of their mutual goodness. She is 
waiting and once he realizes her goodness, he comes to her and her expectation is fulfilled and her faith confirmed.

From this story of love, one might come to the conclusion that Jane belongs to the category of a woman-lover of some ancient tales who waits for her lover. But Austen's Jane belongs to a different category. She relies on her faith in the goodness of man. And that faith is the consequence of her cerebral analysis of the man at very close quarters. She knows that her analysis and consequent understanding of the man cannot go wrong. She has faith in her reasoning and hence she knows that she will not be betrayed. So, in her case, it comes out to be a reasoned love; there is no element of the spontaneous and emotional. Jane and Bingley's happiness are accounted for by the presence of an "excellent understanding and superexcellent disposition of Jane, and a general similarity of feeling and taste between her and himself."3

Her love is always cool and calculative. Since she is cool and calculative, she is not at all impressed by the emotional anxiety shown by her younger sister - Elizabeth. Elizabeth, sometimes, loses her cool and comes out with an emotional outburst against Bingley and Darcy. But Jane does not share the feeling of Elizabeth since, to her; her love is a meeting of one goodness (of herself) with another goodness (of Bingley). So this love takes the abstract form of union of the goodness of the two souls. In the case of such a love, the man cannot beguile the woman for long for once this goodness has been realized on one's own level and understood at the other's level, the union must take place. It cannot be stopped; all constraints and misunderstandings evaporate by themselves. So how easily and comfortably Bingley returns to Jane as if nothing had ever happened between them, as if they have started afresh, leaving all their past behind. Bingley appears to be so cool, calculative and confident. He is so confident in himself being gladly accepted.

People take this short story of love between Jane and Bingley as just an interlude and Jane just a subsidiary of Elizabeth. But it is not so. This little tale has a significance of its own. It is very important - it might be called as a short Prologue to the tale of love between Elizabeth and Darcy. It suggests the importance of a pure character and mind for pure love. The purity of character and mind is the first requisite for and the first step towards pure love. Jane and Bingley illustrate this point. Jane is maturer than Elizabeth. Bingley is maturer than Darcy. People feel that Bingley gets his promptings from Darcy. It is true that they are great friends. But Bingley is always on his own. Darcy has created the confusion of Bingley getting his promptings from himself. Bingley shows no eagerness to deny it; he is a tacit man - going on his own way quietly without any pomp and protest. And he will do what he likes. And that he does in accepting Jane. So they are maturer in the affairs of love.

In this respect, Elizabeth and Darcy are immature since their character is still unformed. They do not have the purity of character and mind necessary for love. Their characters suffer from pride and prejudice. Until and unless they get rid of these two weak spots maligning their characters, they cannot achieve their love. To Austen, love is not an isolated affair - something which has nothing to do with other aspects of life. And it is here that Austen's love takes on a spiritual overtone. Our journey to the realm of spirit requires us first to refine ourselves, to purify ourselves, and to remove all the tints in our character; only then godhood is ours. So is the case with love as depicted in Pride and Prejudice. No tainted character can achieve love. Pride and Prejudice must first be removed. The two words have

3. Austen J. Pride and Prejudice, p.268; chapter 55 
very wide connotations; the reverberations of spirituality are there. They are taken as the two greatest impurities of life and the greatest hurdles to the purity of love-both in the forms of love between a man and God and man and woman. Thus Charlotte Bronte's effort to find the element of the passion - as depicted in her own novels and the novels of Austen's contemporaries - proved to be futile. For with Austen, love is on a different level-it reaches the heights of spirituality. Thus Austen, and with her Jane and Bingley too, seems to be saying - remove the taint and the tint and see the pure light of love. Jane has already done it; she has already achieved the "goodness" in life. Bingley too is good; he wavers till he realizes it. Once realized and achieved love, he is on his way to Jane, to the cherished love.

Elizabeth and Darcy also are serious sojourners. They are bent upon evolving themselves and their love with the help of their reason. They reason out every fault in their character. They falter and fall but they rise again till their evolution is complete.

We shall begin with the evolution of Darcy. Darcy's first step towards evolution is through discovery; he seems like a Botanist who at first feels no fascination for the unseen, unknown flower and rejects it - "not handsome enough to tempt me." ${ }^{4} \mathrm{He}$ might have been carried away by the first flush of emotion. But soon he comes again to that flower and starts dissecting it petal by petal and finds something interesting there. So one curiosity leads to another. So is Darcy -

"But no sooner had he made it clear to himself and his friends that she had hardly a good feature in her face than he began to find it was rendered uncommonly intelligent by the beautiful expression of her dark eyes. To this discovery succeeded some others equally mortifying.Though he had detected with a critical eye more than one failure of perfect symmetry in her form, he was forced to acknowledge her figure to be light and pleasing; and in spite of his asserting that her manners were not those of the fashionable world he was caught by their easy playfulness." 5

The swing is always from the negative to the positive. And that is a good sign for Darcy's love to grow; rather, it shows that the scientist's interest in the object of his scrutiny has taken its root in his mind and heart. There is also every indication that he will pursue his object of interest and his study.

Darcy starts probing to know the response. Probing leads to closeness. But it has its negative side too. Sometimes the attempt to come close generates tension. Positive and negative elements repulse each other. Darcy is trying to be positive but Elizabeth is not in a positive mood. There is thus repulsion. It is not their indifference. They love each other; they know it; only they do not recognize it. They are still like children whose toys are nearby but they think them to be lost; they fret and fume. Love is already there in their hearts; they are trying to seek it here and there - in some simple incidents of love, in their words, in their behavior, in their eyes, in their looks - in some such small external manifestations of love. They are novices and thus, unknowingly, create an atmosphere of tension round about them.

At no time, never, are these two indifferent to each other. Even at the lowest point in their relationship, the least that could be said is that they fancied themselves indifferent when they were only angry. They always converse with each other at a different level than they do with others in the room. Miss Bingley, a very astute observer, senses the tension between

\footnotetext{
4 . Ibid. p. 10; chapter 3.
}

5 . Ibid. p. 19; chapter 6 . 
them from the start, and never misses an opportunity to attack Elizabeth. Her jealousy is palpable and quite justified. It is also striking that their language falls immediately into a kind of intimate shorthand - each catches the other's meaning immediately, and the conversation is conducted at an intimate level which tends to exclude others-for instance, there is a conversation at Netherfield. Miss Bingley addresses Elizabeth, but Elizabeth and Darcy remain so engrossed in their own conversation that Miss Bingley fails to attract Elizabeth to herself. And so she says - "'Do let us have a little music 'cried Miss Bingley, tired of a conversation in which she had no share." ${ }^{6}$ She is tired of this exclusive conversation.

So their love has now entered the love-hate stage. One explicit reason for this lovehate relationship must be their shyness of the society. It is made clear enough in the case of Darcy. He explains his reasons that Mrs. Bennet has given ample evidence of her fortunehunting ambitions for her daughters; one must not allow oneself to be bagged, and "Miss Bingley was uncivil to her (Elizabeth), and more teasing than usual to himself". ${ }^{7}$ So, "He wisely resolved to be particularly careful that no sign of admiration should now escape him, nothing that elevates her with influencing his felicity... ${ }^{8} \mathrm{He}$ resolved not to say a word or do a thing that creates a commotion in the society round about, in the soul and mind of Elizabeth and ruffles Elizabeth's feathers in the wrong way. But he is "steady to his purpose ". ${ }^{9}$ At the same time "he scarcely spoke ten words to her through the whole of Saturday, and though they were at one time left by themselves for half-an-hour, he adhered most conscientiously to his book, and would not even look at her." ${ }^{10}$

So now Darcy is moving ahead consciously with a plan, keeping in mind the family, the society, and Elizabeth. But soon he grows impatient. Psychologists suggest that repressed desire focuses on the specific object which is the cause of repression. Soon it becomes uncontrolled and comes out in the form of blurting of the men and women. And so, one day, Darcy blurts out -

"He sat down for a few moments, and then getting up, walked about the room. Elizabeth was surprised, but said not a word. After a silence of several minutes, he came towards her in an agitated manner, and thus began: 'In vain have I struggled. It will not do. My feelings will not be repressed. You must allow me to tell you how ardently I admire and love you.' "11

But it is not well received. The reasons are explained by these lines -

"He spoke well; but there were feelings besides those of the heart to be detailed; and he was not more eloquent on the subject of tenderness than of pride. His sense of her inferiority of it is being a degradation of the family obstacles which judgment had always opposed to inclination, were dwelt on with a warmth which seemed due to the consequence he was wounding, but was very unlikely to recommend his suit ."12

\footnotetext{
${ }^{6}$. Ibid .p.46; chapter 1 .

7 .Ibid .p.47; chapter 12.

8 .lbid .p.47; chapter 12.

9 .Ibid .p.47; chapter 12.

10.Ibid.p.47; chapter 12.

11 .Ibid.p.147; chapter 34.

12. Ibid. p.148; chapter 34 .
} 
Elizabeth is always against all these extraneous considerations and that has been the cause of her difference with her friend - Charlotte. By spoiling Darcy's chances, Austen too perhaps likes to suggest her dislike of these extraneous considerations in matters of love.

Refusal leads to anger. "His complexion became pale with anger, and the disturbance of his mind was visible in every feature." ${ }^{13}$ Elizabeth, and through her Austen, poses only one question - "I might as well inquire," replied she, " Why with so evident a desire of offending and insulting me, you chose to tell me that you liked me against your will, against your reason, and even against your character ?"14

In the lexicon of love prepared by Austen the three words - "will", "reason", and "character" - have their significant places. Without these, love is no love. It achieves the status of pure love only if these three accompany it. Darcy's love is not yet pure - unmixed with other extraneous considerations. Love is an unalloyed feeling. To Elizabeth, only such a love is acceptable.With each shock that Darcy receives at the hands of Elizabeth, Darcy and his love evolve themselves through understanding and remove each of their weak points.

First, the evolution starts with admiration and appreciation of the innate goodness of Elizabeth. On their first meeting, Darcy overlooks this innate quality of Elizabeth. He is more attentive to her looks and breeding - her family and her relations. Elizabeth's social standing and the indecorum of her family repel Darcy. However, in chapter 33, Darcy's disdain is greatly reduced when he discovers that Elizabeth prefers reading to cards. He now accepts that Elizabeth is cultured and educated despite her upbringing. Darcy may be subconsciously or even purposely referring to Elizabeth when he adds the virtues of extensive reading to the list of qualities he admires in a woman. The subconscious admiration has started to repel and replace his disdain for Elizabeth.

Next to literature comes Dancing. Dancing might be a refinement of polite society, but it is also an attribute of man in the state of nature. In fact, it is associated with love feeling which decorum seeks to control. Thus, dancing is an emotionally charged activity that allows Elizabeth and Darcy's relationship to develop, even though they attempt to repress their emotions. In the beginning, Darcy refuses to dance with her. But soon he realizes his mistake. Darcy remarks to Sir William that "every savage can dance"15 yet because Elizabeth enthralls him, he asks her to dance with him.

Miss Bingley and Mrs. Hurst are entertaining their guests with music. By this time, Darcy is so "bewitched"16 by Elizabeth that if it was not "for the inferiority of her connections, he should be in some danger." ${ }^{17} \mathrm{He}$ remarks about the possibility of falling into this "danger" again after discoursing with Elizabeth as she and Miss Bingley stroll about the room. This happens in chapter 11; strolling, like dance, lends a character grace and gives the character an opportunity at private discourses that reveal deep-felt emotions.

While dancing with Darcy, Elizabeth attempts to decipher his personality. This frustrates him because he feels that she is doing an injustice to his character and that she is

\footnotetext{
13. Ibid.pp.148-49; chapter 34 .

14 . Ibid.p. 149; chapter 34.

15 . Ibid. p.20; chapter 6.

16 . Ibid. p.41; chapter 10.

17. Ibid. p.41; chapter 10.
} 
not enjoying their dance. However, Darcy is so deeply in love with Elizabeth by this time that he feels an indescribable emotion washing over him and forgives her.

At this point, it becomes clear enough that Darcy has achieved a stage of evolution where he has learned to sweep aside his pride and prejudice and to keep his love in the forefront. It is a sheer determination on his part now to keep his character pure-untainted by its previous weaknesses - and thereby achieve the purity of love. It is now the turn of the indescribable emotion of pure love washing over him. At this stage of pure love, the lover works with the principle of forgiving and forgetting when a lover offers himself as a pure, good man and accepts the beloved as a pure, good woman. All reservations are washed away. Darcy's love now is grounded in a well-tested respect for each other's characters. The soundest path is to know and accept the defects of a lover. The defects are to be pushed to the background and the goodness to be brought to the foreground. It will be only goodness matching goodness; this match leads one to the altar of pure love.

Like Darcy, Elizabeth also has to evolve herself from a state of impurity to a state of purity where only goodness remains and all the taints of character-pride and prejudice - are washed away. The match has to be equal. She understands it and thus her effort is on at two levels - keeping an eye on Darcy's progress towards that goal and also reforming herself so that when Darcy is ready she can be a match to him. Elizabeth operates in a world which is not to her liking. Thus the problem that Jane Austen sets up in this novel is how Lizzy is to maintain her integrity and find happiness in the environment in which she lives and which is not at all to her liking. On the thematic level, this problem comes to be as to how love is possible in a ruthless, money-and-status-oriented society. Elizabeth steers her own path - a completely new path full of hurdles both subjective and objective. Since she is born and nurtured in that unsympathetic society and since she is very much a part of that society she has certain inborn and inherited weakness of character; it is her own pride and prejudice. Such a pride and prejudice create hurdles in her way - in the way of better judgment regarding not only herself but also others, especially Darcy. So these hurdles stare in her face.

Unaware of these hurdles she takes an independent course by rejecting mercenary and crude class considerations and scorning subterfuge and design. Her intention is to remain true to her best self by being guided by her heart and by her good sense. However, the question is whether she has got this best self or whether she has still to evolve it. The latter fact is true in her case too. Austen's point is that the heart and feeling must be educated by reason. The course of the novel presents the education of Elizabeth's feelings as she is negotiating her way to pure and perfect love.

Early in the novel, Elizabeth is offended by Darcy. She heartily dislikes him and his aloof manner and class-based pride. She also thinks, not unreasonably, that he dislikes her. This opinion is so firmly rooted in her mind that she fails to notice when his attitude towards her begins to change. Her prejudice blinds her to the reality of his developing passion for her.

The center of the novel and the turning - point in the action occurs when Darcy proposes to Elizabeth. It is done in a hurry and at the wrong moment. For Elizabeth is not going to accept a marriage proposal shorn of love. They are still at the stage of hatred born of pride and prejudice. However, this proposal plays its role well. It is here that they both receive the shocking jolt (to their egos) that precipitates them into journeys of selfunderstanding and begins the education of their hearts. Both the characters are very angry and the combination of high feeling and great wit is exhilarating. An altogether a different sort of person than Mr. Collins, Darcy makes the same conventional assumption. He thinks his 
proposal to Elizabeth will be accepted - because of their relative positions and fortunes. He is wrong, "with an expression of mingled incredulity and mortification"18 he hears her say -

"From the very beginning, from the first moment I may almost say of my acquaintance with you, your manners impressing me with the fullest belief of your arrogance, your conceit, and your selfish disdain of the feelings of others, were such as to form that groundwork of disapprobation on which succeeding events have built so immovable a dislike; and I had not known you a month before I felt that you were the last man in the world whom I could ever be prevailed on to marry." 19

Elizabeth's serious jolt comes the next day when she receives a letter from Darcy explaining his justified reaction to some members of her family and a complete disclosure of Wickham's behavior and character. Her perusal of the letter is mortifying -

"She grew absolutely ashamed of herself...How despicably have I acted!' she cried; 'I, who have prided myself on my discernment! I, who have valued myself on my abilities! who have often disdained the generous candor of my sister, and gratified my vanity in useless or blameable mistrust? How humiliating is this discovery! Yet, how just a humiliation! Had I been in love, I could not have been more wretchedly blind. But Vanity, not love, has been my folly. Pleased with the preference of one, and offended by the neglect of the other, on the very beginning of our acquaintance, I have courted prepossession and ignorance and driven reason away, where either were concerned. Till this moment I never knew myself.' "20

This is the strongest and truest confession about oneself and of one's own weaknesses to which, so far, the confessor had been blind. However, in the savage social world created by the dominance of status and money, the possibility for happiness lies in the ability to change. Elizabeth and Darcy are capable of learning from their humiliating experiences and growing, evolving through this change. They are capable of transformation and, thus, evolution; it is this, Jane Austen tells us, that makes enduring love possible.

Darcy's letter is a success in helping both of the lovers to clarify their thoughts, feelings, and actions. Letters can also be viewed as intimacy separated by time and physical distance. Intimacy blurs perceptions; rationality fails if there is an insufficient distance between mind and object. Letters allow Elizabeth and Darcy to analyze their relationship rationally. And only then they realize that their love is grounded in a well-tested respect for each other's character. Unlike Charlotte who is satisfied with knowing "as little as possible of the defects of the person with whom you are to pass your life ", ${ }^{21}$ Elizabeth decides that the soundest path is to know and accept the defects of her lover, Darcy.

As with letters, so with walking, she visits her sister through the muddy fields to Netherfield. There she makes a very significant remark. Elizabeth's remark -" the distance is nothing when one has a motive; only three miles,"22 parallels her relationship with Darcy. Though the lovers are not physically together often, Elizabeth and Darcy learn more about each other precisely because they are apart and can reflect on their feelings. The naturalness

\footnotetext{
18 .Ibid.p.151; chapter 34.

19 .lbid.p.151; chapter 34.

20 .Ibid.p.162; chapter 36.

21 . Ibid.p. 18 ; chapter 6.

22. Ibid.p. 26 ; chapter 7.
} 
of Darcy's Pemberley landscape appeals to Elizabeth as she strolls through its walks. Like their shared love of literature, Darcy and Elizabeth have similar tastes in landscaping. These two protagonists are closer in spirit than they first realized and their walk together at the end of the novel opens their eyes to this truth.

Literature, dance and walk work as the stepping-stones to the evolution, growth, and purification of their love. They work as eye-openers - opening their eyes not only to their mutual weakness but also to their strength in terms of their basic goodness of spirit and psyche. They realize that innately they are good and that their love is pure. Only they have not yet been able to remove the superflux of social disabilities attached to them because of the fact that they are born social beings and nurtured in their society which fixes its own disabilities and weaknesses on the shoulders of each and every individual - man and woman. Most of the individuals carry this load, willingly or unwillingly, to their graves. A few there are who reason their way out of this incapacity and thus evolve themselves as independent beings, steering their way independently.

They will challenge it and yet will not throw the society down. They will remain in family and society - as much a part of their family and society as other members. Yet they will be above them, like the lotus blooming in the mud and yet above it, shining in its own pure beauty serene. And here we come to the artistic device of Jane Austen - the comic irony. It is through this device that her characters, like her, live their dual life and evolve themselves as perfect human beings creating a world of their own based on their pure spirit of love. This device will be the subject-matter of another research paper.

Facial expressions and eyes have as much a role to play in the evolution of their love as literature, dance and walk. It has been acknowledged that the eyes are windows to the soul. So through them, Darcy tries to reach to the soul of Elizabeth. The slow and unnoticeable change in Darcy's disposition towards Elizabeth is noticeable in his comments on her eyes. Although slighted by Elizabeth who refuses to dance with him, Darcy cannot contain his feelings any longer and tells Miss Bingley that he has been "meditating on the very great pleasure which a pair of fine eyes in the face of a pretty woman can bestow ". ${ }^{23}$ Darcy has been hiding his growing affections for Elizabeth so well that this comment astonishes Miss Bingley.

Before the Bennets leave Netherfield, Bingley talks about Darcy's unruly appearance at his own home and Elizabeth, catching a glimpse of his smile, "perceive(s) that he (is) rather offended, and therefore check(s) that laugh."24 The purpose of this interaction is twofold. Firstly, it shows that Darcy restrains himself in public because of decorum; secondly, it shows that Elizabeth is observing, analyzing and respecting Darcy even though she claims that she is not interested in such a haughty person.

Ambivalence is the co-existence in one person of the emotional attitudes of love and hate, or other opposite feelings, towards the same object or situation. So ambivalent yet passionate are Darcy's feelings towards Elizabeth that the latter seemingly does not know how to interpret his contrariness - why does he watch her all the time despite thinking lowly of her? Elizabeth cannot imagine any reason for Darcy's interest in her other than that there is "something about her more wrong and reprehensible ... than in any other person present." 25

\footnotetext{
23 Ibid.p.25; chapter 6.

24. Ibid.p40; chapter 10.

25 .Ibid.p.40; chapter 11.
} 
When Elizabeth performs on the piano at Rosings, Lady Catherine's house, Darcy leaves Lady Catherine's side to listen to Elizabeth. Elizabeth assumes that Darcy wishes to criticize her and she attacks him, asking "you mean to frighten me, Mr. Darcy, by coming in all this state to hear me?"26She continues to remark that her "courage always rises with every attempt to intimidate (her)"27 More likely, Darcy leaves Lady Catherine because he is disgusted with the latter's demeaning remarks about Elizabeth or perhaps he may truly wish to listen to - and look at - Elizabeth.

"Courage always rises with every attempt to intimidate "- here Elizabeth might have been making a statement only about herself. But its irony is that, indirectly and unknowingly, she is making a statement about the attitude of Darcy too. One word "Courage" indicates the courage of their evolutionary spirit in the face of the intimidation of the subjective and objective negative forces trying to create hurdles in their way and thus obstructing their evolution. At every attempt to rise towards pure love, Darcy slips a step backward. The same is the case with Elizabeth. They suffer because of their pride and prejudice. But they have courage and determination.

Touring Pemberley, Elizabeth pauses to examine a portrait of Darcy. Since Elizabeth now understands Darcy's interference in the Wickham-Georgiana, and Bingley - Jane affairs, she regards Darcy - and his painted likeness - with gratitude and warmth. Elizabeth's submission to Darcy's gaze, mediated here through its representation, is a tacit acceptance of his affection " ... and as she stood before the canvas, on which he was represented, and fixed his eyes upon herself, she thought of his regard with a deeper sentiment of gratitude than it had ever raised before; she remembered its warmth, and softened its impropriety of expression." 28 The joyous expression on Elizabeth's face shows that she may now be deeply in love with Darcy and with his generosity of spirit. However, from her slightly more passive thoughts and actions, it is seen that Elizabeth still does not fully realize this. Though Elizabeth does encourage Darcy's advances through some of her actions, these actions are not active in that they are not consciously done. Darcy is aware that he loves and makes conscious advances towards Elizabeth; she is unaware of the love she feels for him and her advances toward him are unintentional.

In the process of evolutionary love, they have now made certain definite advances towards their goal. The only difference between them is that while Darcy's vision has now grown clear, Elizabeth's vision is still vague. She understands that she is moving towards it and that Darcy too is moving towards it. Only she does not feel its immediate impact while Darcy has started to feel its presence. Until and unless both together feel it, their love is not going to turn itself into a passion. And that is the climax of the evolutionary process. Through reason, love has to evolve itself and reach the passionatehood (an equivalent of Godhood) where the lover and the beloved, irrespective of their weaknesses, achieve oneness of passion. While running after love, they are always haunted by their separateness; in passion, that separateness is converted into oneness; this is unity in diversity of lovers.

Austen's emphasis is not on wanton passion as lauded in the bulk of romantic novels. Her passion is quite distinct from the passion of Charlotte Bronte and Emily Bronte. While their passion takes the shape of turmoil and bewilderment, Austen's passion is calm and satiated. While the one shakes the very existence of man and woman, another gives them an

\footnotetext{
26 .Ibid.p.136 ; chapter 31.

27.Ibid.p.136; chapter 31 .

28. Ibid.p.192; chapter 43.
} 
existence of their own full of peace and satiety, with no desires left-an existence apart from the existence of society and family yet spreading its soothing light on all alike whether it be family and society. When we come to the end of the novel we feel that Austen has also achieved a satiated state. For what after love and marriage? -That is not the concern of Austen. Once the lovers achieve the satiated state of passionatehood, there is the end; once the worshipper achieves the state of Godhood, nobody cares for what is there after that. Austen puts a full-stop to her novel after the achievement of passionate oneness.

As Elizabeth and Darcy walk together towards the Lucases, Elizabeth cannot withhold her emotions any longer and thanks him passionately for preventing the Lydia-Wickham scandal from occurring. The two lovers, who normally have great emotional control, are overwhelmed by their passion for each other. Not only do they speak in a torrent of words, they also feel embarrassed talking about their thoughts and feelings. For when passion overwhelms the lover, words become futile. The priest, the worshipper flooded with the light of Godhood closes his eyes and keeps his mouth shut. Overwhelmed with passion, the two lovers should stop talking. If Elizabeth had met Darcy's eyes, she might have seen how well the expressions of heartfelt delight diffused over his face become him. This is the radiance of the passionate delight. Now the cultural and social control- in the form of pride and prejudice-is over. The lovers now communicate through visual communication. They now discard the means of cultural and social control-the words. These unintentional facial expressions and glances help break down the protagonist's 'pride and prejudice' so gradually that even Elizabeth, a "studier of character", ${ }^{29}$ does not notice the changes. Indeed, Elizabeth's remark about how "people themselves alter so much that there is something new to be observed in them forever" 30 can be applied to herself and to Darcy.

Thus, Austen is not in favor of a love at first sight but is in favor of the slow growth of a rational affection blooming into a passionate union and delight. Darcy aptly describes his gradual and unconscious love for Elizabeth: he was in the middle before he knew that he had begun - "I cannot fix the hour, or the spot, or the look, or the words, which laid the foundation. It is too long ago. I was in the middle before I knew that I had begun". ${ }^{31}$ While still adhering to social norms and decorum, Elizabeth and Darcy are able to shed their pride and prejudice through the natural influences of literature, dance, and facial expression. As these modes of expressions are not immediately apparent in terms of love, they help Elizabeth and Darcy build a relationship that withstands the test of time and of scrutiny. They ultimately build the citadel of pure passionate love.

\section{COMPANIONATE MARRIAGE}

Hand-in-hand the two lovers enter this citadel and reaching the altar of pure passionate love they take a vow to unite themselves into wedlock. Since they are essential parts of this society, they have to adapt themselves to its ways, to the practical ways of life. They have to give a concrete shape and name to this pure spirit of passionate love - the name of marriage. They are not the lovers to abjure their family and society and social relations. They are not the utopian lovers living apart. And that is the characteristic Austenian attitude which creates misunderstanding in the minds of a novelist like Charlotte Bronte and of the modern - day feminists. Marriage is the final realization of this love.

\footnotetext{
29 Ibid .p.34; chapter 9.

30 .Ibid.p.34; chapter 9 .

31 .Ibid.p.294; chapter 60.
} 
However, it is not the marriage as established and defined by the then society. Austen's lovers will not abjure the society yet they will not accept this society's form of marriage. These lovers, like their creator, have their own attitude towards marriage. And the novel Pride and Prejudice is an attempt at defining not only true love but also true marriage. As they have shaped their love so will, they shape their marriage.

The theme of marriage opens itself in the opening sentence of the novel with an ironical attitude. Here money and marriage seem to be going together. This was the reality of the then society. Men married women of wealth; women were forced to unholy alliance for the sake of security. As a realist, Austen does not shut her eyes to this reality of life in the society to which Austen herself belonged. She does not overtly challenge it. But she is also not ready to accept it as an ideal marriage. She shows her dislike of this custom of marriage in her ironical way; this brings us to her method of comic irony. The opening sentence is not just a statement of the bare truth. It also hides Austen's irony that goes with the statement. ${ }^{32}$ Studied minutely, the sentence makes clear her derision of this marriage in vogue in the then society. It is true that her derision is not bitter and biting. Yet it is there, however mild.

In her novel Pride and Prejudice, she has depicted such marriages. Marriages in the eighteenth century were ones of convenience. They were more similar to business arrangement than the union of two inseparable souls. Women and men were sought after according to their wealth and eligibility. Women's property became her husband's when she finally married. Of course, all marriages of all young women had to be approved of by the family. The young women were introduced into society at an early age. The introduction was an indication of their availability. Young girls spent their entire lives preparing for marriage. They learned to read, play the piano, sing and develop other talents in order to increase their desirability as a potential wife. There were many different types of marriages in the eighteenth century. Some marriages were based on love but most were based on the financial security that could be provided. The elder Bennet's marriage was a marriage of security. Mrs. Bennet had a small fortune of her own, as did Mr. Bennet. They did not love each other but stayed together, proving to an extent the family values of the time. Charlotte Lucas married for the sake of getting married and settling down. Her desire to have a family of her own overrode the many failings of the man she married. Charlotte is the antithesis of the conventional romantic heroine. She declares herself that she "never was" 33 a romantic and that "happiness is entirely a matter of chance". ${ }^{34}$ Her marriage to Mr. Collins is for the pure and disinterested desire of an establishment. Jane Austen shows her understanding of such a marriage as the compulsion of the then society. Austen's depiction of Charlotte's "contentment" and Elizabeth's tribute to Charlotte's management of her house and marriage that "it was done very well" ${ }^{35}$ suggest a respect for Charlotte in following her own principles. But, at the same level, Elizabeth rejects the marriage proposal of the same Mr. Collins for she is not Charlotte, and her ideal marriage is quite different.

One of the most striking examples of Austen's satire is her emphasis on reason as opposed to the wanton passion lauded in the bulk of romantic novels. Austen satirizes the general unreality and fairy-tale quality of contemporary romance. Lydia and Wickham's marriage is seen as a triumph of their "passions" over their "virtue"; she is certain that little permanent happiness can arise from such a union" And they are really to be married! ' cried Elizabeth, as soon as they were by themselves. 'How strange this is! And for this we are to be

\footnotetext{
${ }^{32}$ Alquraidhy, K. A. M. S. (2012) Irony-Its Discourse Structure in the Novel. Indian Streams Research Journal, 2 (9).

33 . Ibid p.160; chapter 22.

34 . Ibid.p.18; chapter 6 .

35 .lbid.p.124; chapter 28.
} 
thankful. That they should marry, small as is their chance of happiness, and wretched as is his character, we are forced to rejoice! oh Lydia!"36 This is exemplified by Wickham's continuance of his extravagant habits and the degeneracy of any feeling between them to indifference. The indifference Mr. Bennet has for his wife and the unsatisfactoriness of his marriage is another warning against unthinking passion.

In the novel, we have three broad types of marriage according to the different attitudes of the people concerned: those who would marry for material wealth and social position; those who would marry for just beauty and passion; and, those who would marry for true love with a pure consideration of partner's personal merit.

It is the third type of marriage with which Austen is concerned in this novel. Both the beginning and the end of the novel have their eyes on this marriage. The novel begins with the sentence - "It is a truth universally acknowledged, that a single man in possession of a good fortune must be in want of a wife." ${ }^{37}$ In chapter 61 , we have the sentence - "Happy for all her maternal feelings was the day on which Mrs. Bennet got rid of her two most deserving daughters." ${ }^{38}$ This heavy concentration on marriage in the novel shows Austen's concern both with the subject of topical interest, with the 18th-century social structure and the broad female consciousness. ${ }^{39}$ From the limited consciousness of the then society, Austen expands towards broader feminine consciousness that helps the novel to grow from the particular to the universal. She viewed marriage from two essentially different points of view, describing it, in an intensely critical spirit, as a patriarchal institution and also expressing a visionary ideal of marriage as the ultimate relation. Marriage was, for her, irrevocably associated with oppression, but it was also a profound symbol of community.

Marriage, in the eighteenth century, was a much-maligned institution. It was the most hated compulsion for women. Women preferred marriage which at least gave establishment and status of a wife. Charlotte Lucas, in the novel, belongs to the category of such women. She makes a frank confession of her situation and the facts of life. It shows how a woman was forced to connive at her own subordination and at showing more love than she actually felt for Mr. Collins.

But, as a woman and as a writer, Jane Austen could not accept this deliberate denigration of women and the institution of marriage. In her personal life too, as is clear from her various letters, she spoke against this frustrating situation in which a woman was forced to compromise. Austen knows full well that a plain woman, as well as a beautiful woman, must have something to eat. However, love and not money is the basic requisite for a happy marriage. It is conjectured that she herself had a sleepless night when she agreed to marry without love; and, the next day, she refused.

Her advice to her nieces reveals her considered view about love and marriage. Anna Austen had been engaged to Ben Lefroy intolerable earnestness. The chief objection to this

\footnotetext{
36 .lbid.p. 234 ; chapter 1.

37 .Ibid.p.3; chapter 1

38 .Ibid.p.297; chapter 61 .

39 -The study of marriage as an expression of the broad, universal female consciousness is the point of my divergence from other critics. Every critic finding a mention in the Bibliography dwells on marriage being the focal point in her novel.

Marriage has simply been taken as the social bond/union of hero and the heroine. Sometimes it has been explained in terms of the union of souls. Sometimes their movement to marriage has been explained.

These readings are important. But to me much more important is the study of marriage as an expression of the female consciousness. As in the case of Love, so in the case of Marriage, I have taken it to the mental level; the actual marriage takes place there. That is why in Austen, there is no physical consummation of the marriage of the hero and heroine. It also stops short of the Biological proliferation.
} 
match, according to her, was that he hated the company and she was very fond of it. When there is true love on both sides, the lovers are called the happiest couple in the world. In another letter, the lover is approved for his situation in life, family friends, and above all, his character, his uncommonly amiable mind, strict principles, just notions, good habits. However, she advises her niece not to proceed further unless she intensely loves him. Her nephew records that she herself had rejected the proposal of a gentleman who had everything to recommend him except the power to influence her heart.

Like Austen, her heroine Elizabeth too refuses to be a commodity in the marriage market. Charlotte's advice to Jane is first to secure Mr. Bingley and make herself, thereby, secure. After that, she will have enough opportunity to make love. But Elizabeth disagrees -"' your plan is a good one ', replied Elizabeth,' where nothing is in question but the desire of being well married, and if I were determined to get a rich husband or any husband, I dare say I should adopt it' ". ${ }^{40}$ She makes this protest knowing full well her financial position.

Something of a feminist is in her for, despite her weak financial position, she refuses two marriage offers; one from Mr. Collins who could have offered her enough security and another from Darcy, a man who had at least 10, 000 pounds a year. And she is not repentant. For her, Darcy's conceits, arrogance and selfish disdain for feelings of others outweigh anything else.

Elizabeth shows herself capable enough to single-handedly wage a war against convention and conventional views of women and all the conventional glamour surrounding the institution of marriage. But that single point of coherence has instigated the feminists against Jane Austen. She had been condemned for not rejecting outright this institution - the symbol of woman's subjugation.

Austen began by emphasizing the injustices done to women. But Austen would not stop there. Her protests start from personal and middle-class woman's conditions but soon they take on a universal significance in the form of feminine consciousness. It was a part of her broad moral consciousness which could not deny or neglect the social existence based on human interdependence, cooperation, and adaptation. Removing her pride and prejudice, Elizabeth takes recourse to this consciousness and achieves the happiness of her life and also guarantees the happiness of others. Her feminine consciousness thus becomes a part of the greater social consciousness developed by her as well as by her creator - for the sake of collective survival as well as individual security and fulfillment. And that is where Austen differs from the staunch feminists. Whereas they stand only for the individual woman and reject outright the collective society and family, Austen stands for both for in her feminine consciousness the good of the two is inevitably aligned. So the rejection of the society, of family and marriage, is not the pre-requisite of the assertion of individuality. It is true that the individual looks askance at this society but he is never in a mood to reject it outright. For its presence is a guarantee of his release. In Austen, cooperation is not humiliation and submission. Rather the uncooperative self is often the debased self.

This female consciousness works through a woman's intellect. This female consciousness attached to a woman's intellect is a prism through which she sees not only the older generation but also herself and her individuality. A study of the older generation gives her a chance to evaluate herself and find out her identity. Not only this, she extends her vision from the older generation and herself to the man before her. She finds out his identity too, moves towards him and makes him move towards herself so that the two can fuse in marriage

40 .Austen, J.Pride and Prejudice, p.18; chapter 6. 
and happy family life and move together to revitalize their past generation and tradition and to move ahead, to guide the next generation. Such is the extension of the female consciousness of her heroine. But the first step towards that female consciousness is taken by the heroine.

At the end of the novel, Elizabeth and Darcy marry. It is a different marriage seen in a different light. It is in opposition to the common conception of marriage between the acquiescent woman who will be ruled by the superior moral nature and judgment of the man. It is the model of a companionate marriage. This union is advantageous to both. They will cooperate now - instead of rivalry there will be cooperation; Darcy will come forward with his judgment and knowledge of the world; Elizabeth will come forward with her ease and liveliness of manner. Together the intellect and intuition make the complete whole. Thus Austen's emphasis is on what a man and woman have to give each other, on the mystery of completion and not on the discussion of separate superiorities. Her feminism is for profound adjustments in the inner lives of the sexes. Marriage is a consummation of the two unitsmasculine and feminine. They must conduct their lives so as to give each element expression and to join both into a harmonious whole. It is the result of this reconciliation that Darcy is now willing to be an object of open pleasantry. Georgiana Darcy is amazed at her brother's change. All this was not possible prior to their marriage. A truly fulfilling marriage, it appears in Pride and Prejudice, can only exist between partners of whom both have mature and developed characters, as Darcy and Elizabeth have.

With this love and marriage, they are among the happiest persons on the earth. Elizabeth feels so-"'I am the happiest creature in the world. Perhaps other people have said so before, but no one with such justice. I am happier even than Jane; she only smiles, I laugh."'41

\section{REFERENCES}

\section{Novels of Jane Austen}

Austen, J. Pride and Prejudice (M. Abbas, Ed.). Egypt: The Anglo Egyptian Bookshop.

Austen, J. (2002). Emma. Delhi: UBSD.

\section{Works on Jane Austen}

Alquraidhy, K. A. M. S. (2012). Irony-Its Discourse Structure in the Novel. Indian Streams Research Journal, 2(9).

Bulter, M. (1988). Jane Austen and the war of ideas. Clarendon Press.

Copeland, E., \& McMaster, J. (Eds.). (1998). The Cambridge Companion to Jane Austen. Cambridge University Press.

Gillie, C. (1974). A Preface to Jane Austen. Longman.

Gooneratne, Y. (1970). Jane Austen. Cambridge University Press.

Hardy, B. (1979). Reading of Jane Austen. A\&C Black.

41. Ibid. p.296 : chapter 60. 
Jones, V. (1997). How to study a Jane Austen novel. Macmillan.

Kirkham, M. (1986). Jane Austen, Feminism and Fiction. The Harvester Press.

Lascelles, M. (1963). Jane Austen and Her Art. Oxford University Press.

Mansell, D. (1973). The novels of Jane Austen: an interpretation. Macmillan International Higher Education.

Monaghan, D. (1980). Jane Austen: Structure and Social Vision. Macmillan.

Mudrick, M. (1952). Jane Austen: Irony as defense and discovery. Princeton University Press.

O’Neill, J. (1970). Critics on Jane Austen (Readings in literary Criticism). Allen and Unwin.

Pinion, F. B. (1973). A Jane Austen companion: a critical survey and reference book. Macmillan.

Reddy, T. V. (1987). Jane Austen: the Matrix of Matrimony. Bohra Publications.

Roberts, W. (2001). Jane Austen and the French Revolution. Palgrave Macmillan.

Rubinstein, E. (Ed.). (1969). Twentieth century interpretations of Pride and prejudice: a collection of critical essays. Prentice-Hall.

Sahney, R. (1990). Jane Austen's heroes and other male characters: a sociological study. Abhinav Publications.

Singh, S. (1981). Jane Austen: Her Concept of Social Life. S. Chand. 